\title{
Teori dan Praktik Berkontrak dengan Penyedia Kerja Sama Operasi (KSO) dalam Pengadaan Barang/Jasa Pemerintah
}

\author{
Ajik Sujoko \\ Fungsional Pengelola Barang/Jasa, Fakultas Hukum Undip \\ Jl. Prof. Soedarto, SH Tembalang Semarang \\ email: ajik.sujoko80@gmail.com
}

\begin{abstract}
In the practice of Government Goods / Services Procurement (PBJP), especially in construction services known as Operational Cooperation (KSO). KSO is interesting to discuss in PBJP because many large-scale government projects undertaken by providers with KSO and KSO are allowed according to PBJP regulations. However, in the practice of $\mathrm{KSO}$ in PBJP there is no uniformity or standard form of KSO what should be done in practice until the issuance of Perpres number 16 of 2018. Based on the application of contracting with KSO providers, it can be seen that the tendency to apply a combination of the characteristics of the form of KSO Administration and KSO Non-Administration. As a KSO that is commonly used in PBJP which has various applications in practice.
\end{abstract}

Keywords: Joint Operation, Government Procurement of Goods / Services

\begin{abstract}
Abstrak
Dalam praktik Pengadaan Barang/Jasa Pemerintah (PBJP), khususnya dalam jasa konstruksi dikenal Kerja Sama Operasi (KSO). KSO menarik untuk didiskusikan dalam PBJP karena banyak proyek skala besar pemerintah yang dikerjakan oleh penyedia yang ber-KSO dan KSO diperbolehkan menurut peraturan PBJP. Namun demikian, dalam praktik KSO di PBJP terdapat belum ada keseragaman atau bentuk baku KSO harus seperti apa dalam praktiknya sampai terbitnya Perpres nomor 16 Tahun 2018. Berdasar penerapan berkontrak dengan penyedia KSO dapat dilihat bahwa kencenderungan menerapkan gabungan dari ciri-ciri bentuk KSO Administrasi dan KSO Non Administrasi. Sebagai KSO yang biasa dipakai dalam PBJP yang memiliki beragam penerapan dalam prakteknya.
\end{abstract}

Keywords: Joint Operation, Government Procurement of Goods/Services

\section{A. Pendahuluan}

Joint venture execution is different than the conventional types of procurement; contractor's joint venture involved two or more parties formed a joint venture. The strategy is for the reason that to achieve their business goal, as they opt for high-risk 
investment by engaged in partnership and joint venture pattern of contracting. ${ }^{1}$ Kerja sama atau ventura bersama (joint venture) adalah suatu strategi bisnis yang relatif banyak dipergunakan oleh perusahaan-perusahaan baik di dunia maupun di Indonesia. ${ }^{2}$ Bentukbentuk kerja sama yang sangat beragam dalam perkembangannya banyak dipakai dan menjadi penyedia dalam pekerjaan di pemerintah.

Dalam praktik Pengadaan Barang/Jasa Pemerintah (PBJP), khususnya dalam jasa konstruksi masih dikenal dengan istilah Kerja Sama Operasi (KSO). KSO menarik untuk didiskusikan dalam PBJP karena: 1). banyak nilai proyek skala besar pemerintah yang dikerjakan oleh penyedia yang ber-KSO dan 2). KSO diperbolehkan menurut peraturan pengadaan barang/jasa pemerintah.

Namun demikian, dalam praktik KSO di PBJP terdapat; Pertama, belum ada keseragaman atau bentuk baku KSO harus seperti apa dalam praktiknya sampai terbitnya Perpres nomor 16 Tahun 2018. Dan Kedua, perkembangan laporan keuangan berdasar Pernyataan Standar Akuntansi Keuangan (PSAK) yang berubah sejak PSAK 39 sampai dengan PSAK 66. sebagaimana diketahui bahwa akuntansi atas pengaturan bersama diatur dalam PSAK 66. Ketentuan dalam PSAK 66 menggantikan PSAK 12 Pengendalian Bersama dan PSAK 39 Kerjasama Operasi. Pengaturan dalam PSAK 66 bersifat pinciples based $^{3}$. Dari uraian di atas, melalui tulisan ini untuk mendiskusikan mengenai Teori dan Praktik Administrasi Berkontrak dengan Penyedia Kerja Sama Operasi (KSO) dalam Pengadaan Barang/Jasa Pemerintah.

\section{B. Pembahasan}

\section{Pola-Pola Kontrak dalam Pengadaan Barang/Jasa Pemerintah melalui Penyedia}

Dalam praktek penyelenggaran Kontrak dalam Pengadaan Barang/Jasa Pemerintah terdapat pola pola yang sengat beragam. Pola pola tersebut muncul

\footnotetext{
${ }^{1}$ Norsyakilah Romeli*, Faridah Muhamad Halil, Faridah Ismail, Ani Saifuza Abd Shukor, Economic Challenges in Joint Venture Infrastructure Projects: Towards Contractor's Quality of Life, Procedia - Social and Behavioral Sciences 234 ( 2016 ) 19-27. hlm. 20.

${ }^{2}$ Joint Operations and Joint Venture: IFRS 11/PSAK 66, Konsep, Struktur, Akuntansi dan Perpajakan di Indonesia, $\quad$ https://futurumcorfinan.com/wpcontent/uploads/2015/11/Joint_Venture_training_syllabus_Futurum_Corfinan-for-public.pdf, diunduh tanggal 16 Desember 219, jam 09.48 WIB.

${ }^{3}$ Dwi Martani, Pengaturan Bersama PSAK 66, https://staff.blog.ui.ac.id/martani/2018/03/15/pengaturanbersama-psak-66/, diunduh tanggal 16 Desember 2019, jam 12.15
} 
karena praktek penyelenggaraan barang dan jasa serta beradasarkan pada peraturan perundang undangan yang berlaku. Secara normatif, konsep pengadaan barang dan jasa telah diatur dalam Pasal 1 butir 1 KepPres No. 54 Tahun 2010, yaitu kegiatan untuk memperoleh barang dan jasa oleh Kementrian/Lembaga/Satuan Kerja Perangkat Daerah/Institusi lainnya yang prosesnya dimulai dari perencanaan kebutuhan sampai diselesaikannya seluruh kegiatan untuk memperoleh barang dan jasa.

Proses pengadaan barang dan jasa ini rawan terjadi korupsi, mulai dari tahap perencanaan sampai dengan tahap pelaksanaan kontrak. Hal ini sejalan dengan penyataan Organisation For Economic Co-Operation And Development (OECD) yang menyatakan: “....as the government activity most vulnerable to corruption. As a major interface between the public and the private sectors, public procurement provides multiple opportunities for both public and private actors to divert public funds for private gain”. Beberapa pola kontrak dalam Pengadaan Barang/Jasa Pemerintah melalui Penyedia dapat dilihat dari gambar berikut:

Gambar 1. Pola kontrak yang umum diterapkan dalam pekerjaan di pemerintah :

Pemerintah

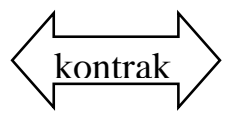

Penyedia

Gambar 2. Pola kontrak yang umum diterapkan dalam pekerjaan di pemerintah yang terdapat subkontraktor/subpenyedia jasa. ${ }^{4}$

Pemerintah

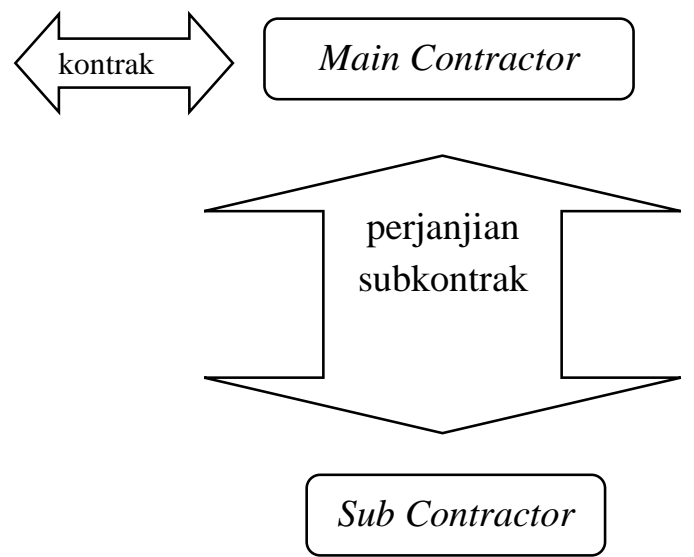

${ }^{4}$ Ajik Sujoko, Permasalahan Subkontrak Pada Pekerjaan Konstruksi di Pemerintah, Adminitrative Law \& Governance Journal. Volume 2 Issue 3, August 2019, hlm. 432. 
Gambar 3. Pola kontrak yang umum diterapkan dalam pekerjaan di pemerintah yang terdapat subkontraktor/subpenyedia jasa.

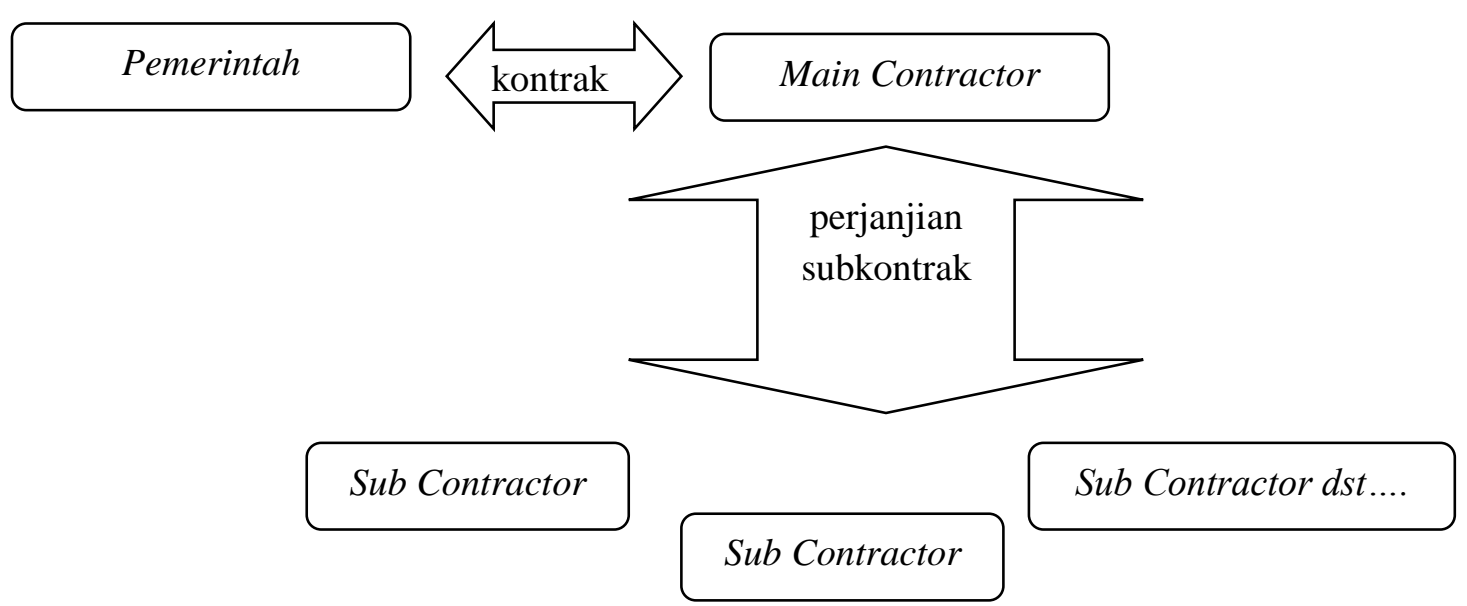

Gambar 4. Pola kontrak yang umum diterapkan dalam pekerjaan di pemerintah dengan KSO, di mana tanda tangan kontrak diwakili oleh Leadfirm KSO berdasarkan Perjanjian KSO.

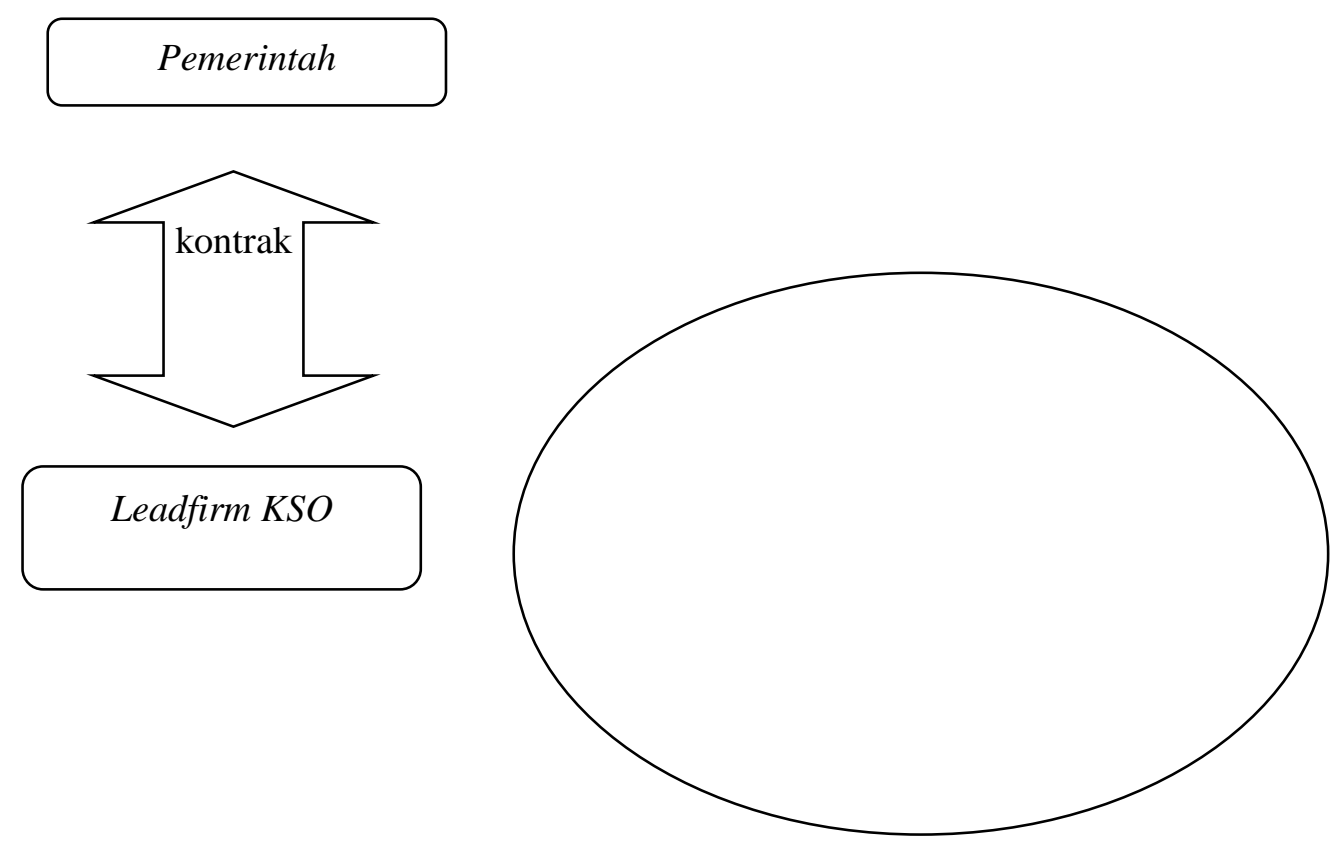


Gambar 5. Pola kontrak yang dapat diterapkan dalam pekerjaan di pemerintah dengan KSO, di mana tanda tangan kontrak dilakukan oleh semua peserta KSO berdasar Perjanjian KSO.

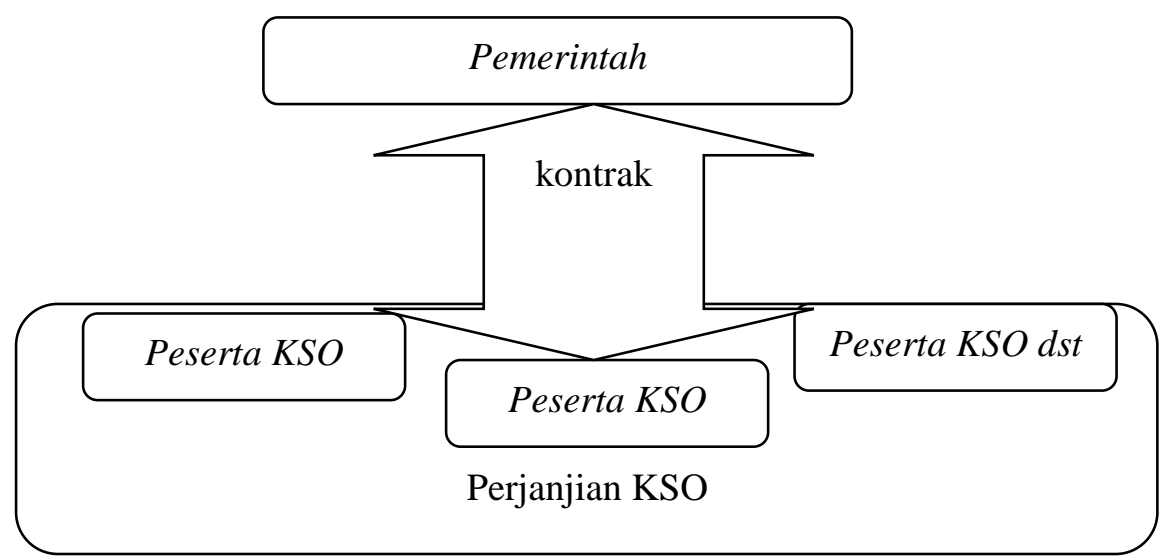

Gambar 6. Pola kontrak yang umum diterapkan dalam pekerjaan di pemerintah dengan KSO dan terdapat subkontraktor/sub penyedia jasa.

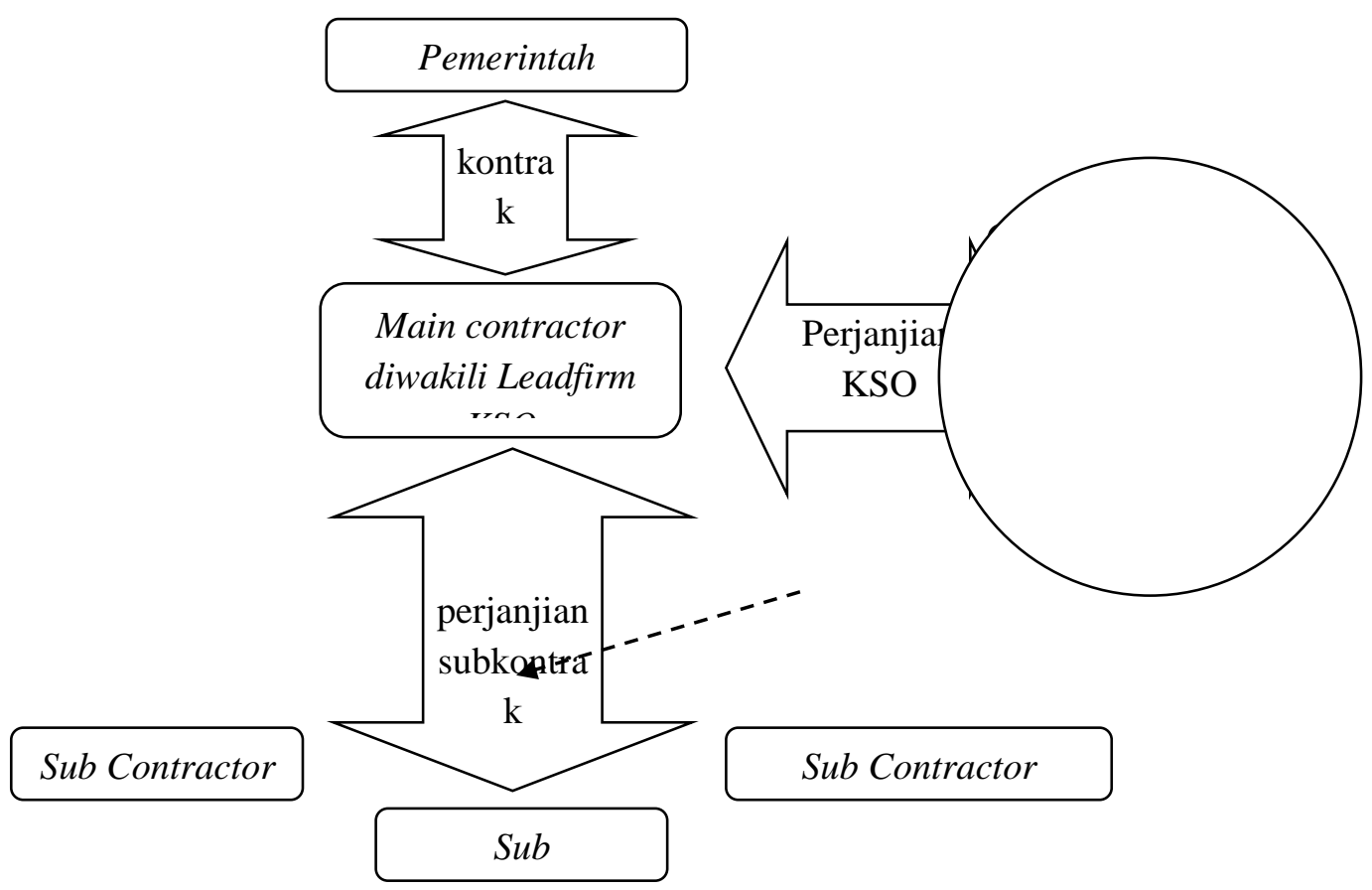


Gambar 7. Pola kontrak yang mungkin diterapkan dalam pekerjaan di pemerintah dengan KSO dan terdapat subkontraktor/sub penyedia jasa.

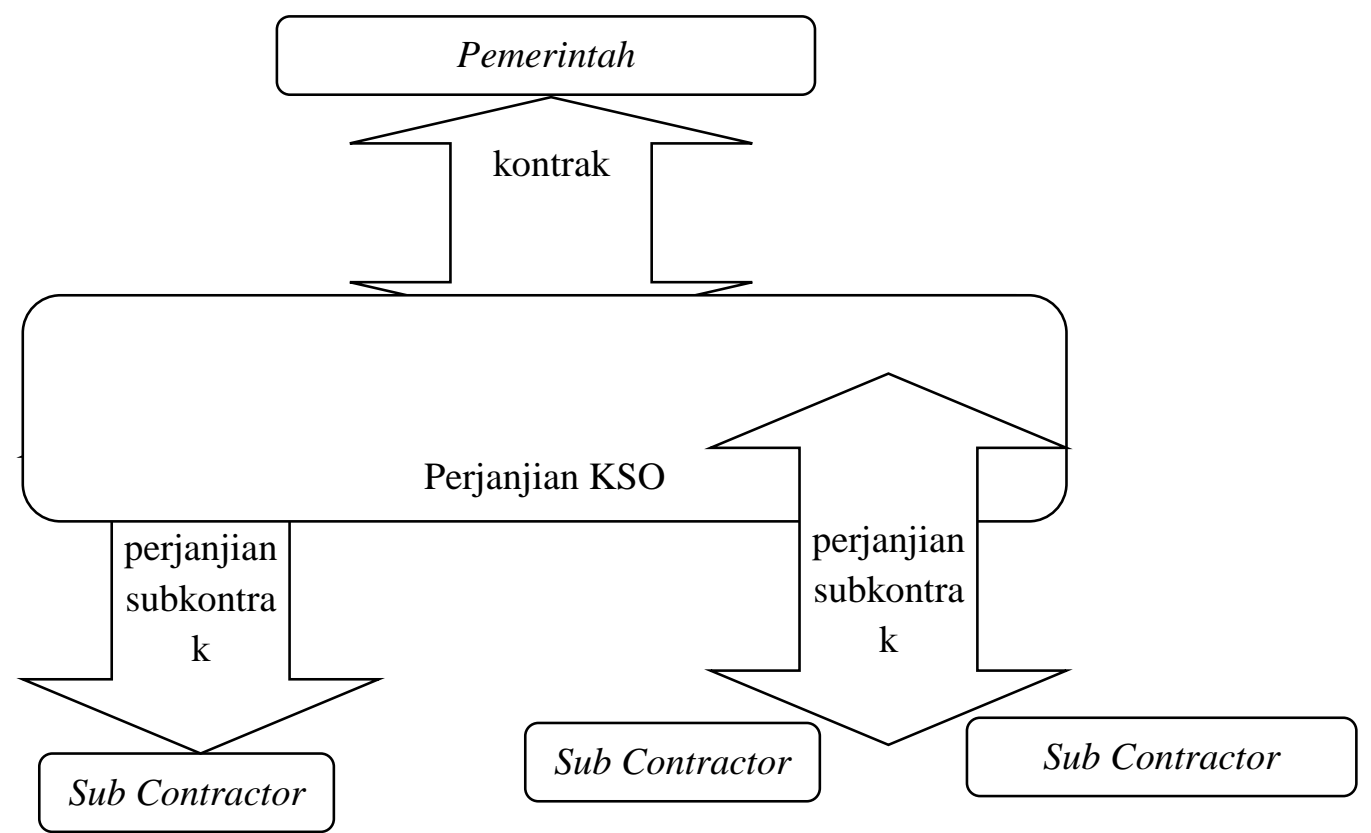

2. Kerja Sama Operasi (KSO)

\subsection{Definisi Kerja Sama Operasi (KSO)}

Perjanjian kerja sama operasi (KSO) adalah perjanjian antara dua pihak atau lebih yang sepakat bersama-sama menyelesaikan suatu proyek, baik yang membentuk entitas hukum baru (administrative JO) maupun tanpa membentuk entitas hukum baru (non administrative JO). ${ }^{5}$ Beberapa definisi mengenai Kerja Sama Operasi (KSO) telah dibakukan dalam beberapa peraturan perundangundangan. Menurut Pasal 1 angka (14) 740/KMK.00/1989 tentang Peningkatan Efisiensi Dan Produktivitas Badan Usaha Milik Negara, KSO adalah: "Kerjasama antara dua pihak atau lebih untuk bersama-sama melakukan suatu kegiatan usaha guna mencapai suatu tujuan tertentu”. Menurut Angka 11 Bab I.IV Permen BUMN 13/2014 tentang Pedoman Pendayagunaan Aset Tetap Badan Usaha Milik Negara, KSO adalah: "Kerjasama dengan prinsip bagi hasil yang saling menguntungkan antara BUMN dengan mitra kerjasama, dimana BUMN ikut terlibat dalam manajemen pengelolaan.”

${ }^{5}$ Eka Suci Mauliyani, Ahmadi Miru, Nurfaidah Said, Kedudukan Perjanjian Kerja Sama Operasi (KSO) Dalam Hukum Perusahaan Di Indonesia, Analisis, Desember 2013, Vol.2 No.2 : 193 - 200, hlm. 193. 
KSO Sebagai suatu perjanjian tidak bernama (innominaat) selalu diidentikkan dengan "Persekutuan Perdata" atau "Maatschap" (Partnership) atau "burgerlijk maatschap" (civil partnership) sebagaimana yang ditentukan dalam Pasal 1618 s/d Pasal 1665 KUHPerdata tentang Persekutuan. ${ }^{6}$ Persekutuan Perdata (partnership / maatschap) menurut pasal 1618 KUHPerdata adalah perjanjian antara dua orang atau lebih mengikatnya diri untuk memasukkan sesuatu (inbreng) ke dalam persekutuan dengan maksud membagi keuntungan yang diperoleh karenanya.

\subsection{Bentuk Kerja Sama menurut Pernyataan Standar Akuntansi Keuangan (PSAK)}

Dalam Pernyataan Standar Akuntansi Keuangan (PSAK) 39/1997, bentukbentuk KSO berkembang dengan berbagai variasi, namun demikian bisa dibagi menjadi dua golongan yakni: ${ }^{7}$

a. KSO dengan entitas hukum yang terpisah (separate entity) dari entitas hukum para partisan KSO.

b. KSO tanpa pembentukan entitas hukum yang terpisah.

Dapat disimpulkan mengenai KSO bahwa: ${ }^{8}$

- KSO melibatkan dua pihak atau lebih dengan masing-masing memasukkan sesuatu (inbreng) kedalam persekutuan (KSO) (vide: Pasal 1618 Jo. Pasal 1628 KUHPerdata).

- Untuk membedakan suatu perjanjian termasuk dalam KSO atau bukan, terletak dari apakah para pihak melakukan suatu kegiatan usaha secara bersama atau tidak (vide: Pasal 1619 KUHPerdata).

- Kegiatan usaha tersebut harus dikelola secara bersama dengan tujuan untuk mencari suatu keuntungan secara bersama (vide: Pasal 1636 dan Pasal 1647 KUHPerdata).

- Tidak terdapat ketentuan yang mewajibkan KSO harus berbentuk entitas baru yang terpisah dari partisan KSO.

\footnotetext{
${ }^{6}$ Almaududi, Apa yang Dimaksud Dengan Kerjasama Operasi (KSO)?, https://almaududi.com/2019/01/05/apa-yang-dimaksud-dengan-kerjasama-operasi-kso/, diunduh tanggal 16 Desember 2019, jam 11.26 WIB.

7 Almaududi, Apa yang Dimaksud Dengan Kerjasama Operasi (KSO)?, https://almaududi.com/2019/01/05/apa-yang-dimaksud-dengan-kerjasama-operasi-kso/, diunduh tanggal 16 Desember 2019, jam 11.26 WIB.

8 Almaududi, Apa yang Dimaksud Dengan Kerjasama Operasi (KSO)?, https://almaududi.com/2019/01/05/apa-yang-dimaksud-dengan-kerjasama-operasi-kso/, diunduh tanggal 16 Desember 2019, jam 11.26 WIB.
} 
- Tidak tertutup kemungkinan untuk mengadakan KSO dalam rangka menyelesaikan suatu proyek tertentu, yang bersifat sementara hingga proyek selesai (vide: Pasal 1649 KUHPerdata).

Pernyataan Standar Akuntansi Keuangan (PSAK)12 (Revisi 2009) dikenal istilah joint venture. Ruang lingkup pengendalian bersama padajoint venture, meliputi: ${ }^{9}$

(1) Pengendalian bersama operasi. Joint venture dengan pengendalian bersama operasi, umumnya melibatkan penggunaan asset dan sumber daya lainnya oleh venturer. Dalam hal ini setiap venturer dapat menggunakan asset tetap dan persediaannya untuk melaksanakan operasi joint venture.

(2) Pengendalian bersama aset. Joint venture dengan kontrak pengendalian bersama aset atau kepemilikan bersama asset berarti asset tersebut oleh venture atas satu atau lebih aset yang dikontribusikan kepada atau diperoleh untuk tujuan dari joint venture dan didedikasikan untuk tujuan joint venture pula. Aset tersebut digunakan untuk memperoleh manfaat bagi venturer. Setiap venturer dapat mengambil suatu bagian keluaran dari aset dan menanggung suatu bagian yang disetujui dari beban yang terjadi.

(3) Pengendalian bersama entitas. Joint venture dengan kontrak pengendalian bersama entitas, diikuti dengan pendirian perseroan terbatas, persekutuan atau entitas lainnya yang mana setiap venturer mempunyai bagian partisipasi. Entitas tersebut beroperasi dalam cara yang sama seperti entitas lainnya, kecuali adanya perjanjian kontraktual antar venturer yang menciptakan pengendalian bersama atas aktivitas ekonomi entitas.

Exposure Draft Pernyataan Standar Akuntansi Keuangan (ED PSAK) 66

mengklasifikasikan pengaturan bersama hanya menjadi dua yaitu; ${ }^{10}$

(1) Operasi bersama (joint operation). Operasi bersama adalah pengaturan bersama yang mengatur bahwa para pihak yang memiliki pengendalian bersama atas pengaturan memiliki hak atas aset dan kewajiban terhadap liabilitas terkait dengan pengaturan tersebut. Para pihak tersebut disebut operator bersama.

(2) Ventura bersama (joint venture). Ventura bersama adalah pengaturan bersama yang mengatur bahwa para pihak yang memiliki pengendalian bersama atas pengaturan yang memiliki hak atas aset neto pengaturan tersebut.

\subsection{Pembagian Kerja Sama Operasi $\left(\right.$ KSO) ${ }^{11}$ dari Aspek Perpajakan}

${ }^{9}$ Istutik, Bentuk Joint Venture dalam PSAK 12 (Revisi 2009), http://blog.stiemce.ac.id/istutik/2012/02/29/bentuk-ventura-bersama-dalam-psak-12-revisi-2009/, diunduh tanggal 18 Desember 2019, jam 10.38 WIB.

$10 \quad$ Ikatan Akuntansi Indonesia, 2013, Exposure Draft Pernyataan Standar Akuntansi Keuangan ED PSAK 66 Pengaturan Bersama, Jakarta, Dewan Standar Akuntansi Keuangan Ikatan Akuntan Indonesia, hlm v.

${ }^{11}$ Syarat, Tata Cara dan Dasar Hukum Kemitraan KSO, https://www.pengadaan.web.id/2017/11/syarat-tatacara-dan-dasar-hukum-kemitraan-kso.html, diunduh tanggal 16 Desember 2019, jam 13.53 WIB. 
Secara garis besar, terdapat 2 (dua) jenis KSO, yaitu KSO yang terpisah dari anggotanya dan KSO yang tidak terpisah dari anggotanya. KSO yang terpisah dari anggotanya sering disebut sebagai KSO Administratif, artinya administrasi usaha sepenuhnya dilakukan atas nama KSO, mulai dari pengajuan tender PBJ, penandatanganan kontrak kerja hingga penagihan hasil kerja atau penerbitan invoice. KSO yang kedua sering disebut sebagai KSO Non Administratif. Kontrak kerja dilakukan atas nama masing-masing anggota KSO dan tanggungjawab kerja ada pada masing-masing anggota KSO. Atau dengan kata lain, dalam hal ini KSO hanya ditujukan sebagai alat koordinasi para anggotanya saja.

\subsubsection{KSO Administratif}

Sebagai entitas yang terpisah dari anggotanya, KSO Administratif harus memiliki NPWP sendiri. Adapun untuk memperoleh NPWP (Nomor Pokok Wajib Pajak) dan NPPKP (Nomor Pengukuhan Pengusaha Kena Pajak), KSO harus mengisi formulir Permohonan Pendaftaran dan Perubahan Data Wajib Pajak yang telah diisi dan menandatanganinya. Tidak hanya mengisi dan menandatangani formulir yang sesuai, dokumen-dokumen di bawah ini juga wajib dilampirkan pada formulir pendaftaran NPWP KSO:

a. Fotokopi Perjanjian Kerjasama sebagai KSO;

b. Fotokopi Kartu NPWP masing-masing anggota KSO;

c. Fotokopi Kartu Tanda Penduduk bagi penduduk Indonesia, atau Paspor ditambah surat keterangan tempat tinggal dari instansi yang berwenang (sekurang-kurangnya lurah atau kepala desa bagi orang asing), dari salah seorang pengurus KSO.

Karena KSO Administratif merupakan entitas yang berbeda dari para anggotanya, maka setiap penyerahan barang atau jasa anggota kepada KSO ataupun sebaliknya dapat memiliki implikasi perpajakan. Dengan demikian jika KSO telah memiliki NPWP dan menjadi Pengusaha Kena Pajak (PKP), KSO wajib:

a. Memotong pajak atas pembayaran yang menjadi Objek Pemotongan $\mathrm{PPh}$ kepada anggota KSO, ataupun sebaliknya; dan

b. Memungut PPN atas penyerahan Barang Kena Pajak (BKP) dan/atau Jasa Kena Pajak (JKP) kepada anggota KSO, ataupun sebaliknya.

Seiring dengan kepemilikan NPWP, KSO Administratif harus menyelenggarakan pembukuan sendiri yang terpisah dari para anggotanya, dimana pembukuan tersebut pada dasarnya adalah sama dengan pembukuan perusahaanperusahaan lain.

\subsubsection{KSO Non Administratif}

Karena tidak menjadi entitas usaha yang terpisah dari anggotanya, KSO Non Administratif tidak perlu didaftarkan untuk memiliki NPWP. Dan karena tidak menjadi entitas yang berbeda dari para anggotanya, tidak ada aspek perpajakan atas setiap penyerahan barang dan/atau jasa dari anggota KSO ke KSO ataupun sebaliknya. Mengingat KSO Non Administratif bukan entitas usaha yang berdiri sendiri, KSO Non Administratif dapat mengabaikan penyelenggaraan pembukuan yang khusus bagi KSO. Pembukuan dapat dicatat oleh masing-masing anggota 
KSO. Namun akan lebih baik jika pembukuan khusus untuk KSO MBA tetap diselenggarakan, antara lain agar:

a. Masing-masing anggota KSO dapat mengetahui jumlah dan jenis kontribusi yang diberikan terhadap $\mathrm{KSO}$;

b. Masing-masing anggota KSO dapat mempertanggungjawabkan keuntungan yang diperoleh dari KSO, begitupun sebaliknya; dan

c. Masing-masing anggota KSO dapat menilai kinerja bisnis MBA.

\subsection{Penyedia Kerja Sama Operasi (KSO) menurut Peraturan Presiden nomor 16 tahun 2018 tentang Pengadaan Barang/Jasa Pemerintah dan aturan pelaksananya}

Di dalam Peraturan Presiden nomor 16 tahun 2018 mengatur kebijakan mengenai kerja sama yang diikuti oleh Badan usaha asing dan penyedia usaha nonkecil. Menurut Pasal 63 ayat (3) Peraturan Presiden nomor 16 tahun 2018, Badan usaha asing yang mengikuti Tender/Seleksi Internasional sebagaimana dimaksud pada ayat (1), harus melakukan kerja sama usaha dengan badan usaha nasional dalam bentuk konsorsium, subkontrak, atau bentuk kerja sama lainnya. Dalam Pasal 65 ayat (6) Peraturan Presiden nomor 16 tahun 2018 dijelaskan bahwa penyedia usaha non-kecil yang melaksanakan pekerjaan dapat melakukan kerja sama usaha dengan usaha kecil dalam bentuk kemitraan, subkontrak, atau bentuk kerja sama lainnya, jika ada usaha kecil yang memiliki kemampuan di bidang yang bersangkutan.

Lebih lanjut dalam Peraturan LKPP Nomor 9 Tahun 2018 tentang Pedoman Pelaksanaan Pengadaan Barang/Jasa Melalui Penyedia mengatur rinci persyaratan bagi penyedia yang akan melakukan konsorsium/kerja sama operasi/kemitraan/bentuk kerjasama lain. Dijelaskan dalam angka 3.4.1 mengenai syarat kualifikasi administrasi/legalitas penyedia barang/jasa huruf I, bahwa dalam hal peserta akan melakukan konsorsium/kerja sama operasi/kemitraan/bentuk kerjasama lain harus mempunyai perjanjian konsorsium/kerja sama operasi/kemitraan/bentuk kerjasama lain. Selanjutnya dijelaskan dalam angka 3.5 Kemitraan dalam hal sifat dan lingkup pekerjaan yang terlalu luas, atau jenis keahlian yang diperlukan untuk menyelesaikan pekerjaan tidak dapat dilakukan oleh 1 (satu) Penyedia, maka: 
a. diberikan kesempatan yang memungkinkan para Penyedia saling bergabung dalam suatu konsorsium/kerja sama operasi/kemitraan/bentuk kerjasama lain; dan/atau

b. diberikan kesempatan yang memungkinkan Penyedia atau konsorsium/kerja sama operasi/kemitraan/bentuk kerjasama lain Penyedia untuk menggunakan tenaga ahli asing

Selanjutnya dalam angka 2.3.2.3 Naskah Perjanjian, angka 5) Para Pihak dalam Kontrak dijelaskan. Para Pihak dalam Kontrak;

a) Menjelaskan secara rinci dan menerangkan hal yang sebenarnya identitas para pihak yang meliputi nama, jabatan dan alamat serta kedudukan para pihak dalam Kontrak tersebut, apakah sebagai pihak pertama atau pihak kedua.

b) Para pihak dalam Kontrak terdiri dari dua pihak yaitu:

(1) pihak pertama adalah pihak Pejabat Penandatangan Kontrak (PA/KPA/PPK);

(2) pihak kedua adalah pihak Penyedia yang telah ditunjuk untuk melaksanakan pekerjaan;

(3)menjelaskan pihak-pihak tersebut bertindak untuk dan atas nama siapa dan dasar kewenangannya; dan

(4)apabila pihak kedua dalam Kontrak merupakan suatu konsorsium/kerja sama operasi/kemitraan/bentuk kerjasama lain maka harus dijelaskan nama bentuk kerjasamanya, siapa saja anggotanya dan siapa yang memimpin dan mewakili kerja sama tersebut.

Menurut Peraturan Presiden nomor 16 tahun 2018 dan aturan pelaksanya, kerja sama usaha dapat dilakukan antara penyedia usaha non-kecil dengan usaha kecil. Pelaku usaha yang akan melakukan kerja sama operasi harus mempunyai perjanjian kerja sama operasi.

\subsection{Penyedia Kerja Sama Operasi (KSO) menurut Undang-Undang nomor 2 tahun 2017 tentang Jasa Konstruksi}

Pasal 32 Undang-Undang nomor 2 tahun 2017 tentang Jasa Konstruksi dijelaskan bahwa Badan usaha Jasa Konstruksi Asing atau usaha perseorangan Jasa 
Konstruksi asing yang akan melakukan usaha Jasa Konstruksi di wilayah Indonesia wajib membentuk:

a. kantor perwakilan; dan/atau

b. badan usaha berbadan hukum Indonesia melalui kerja sama modal dengan badan usaha Jasa Konstruksi nasional.

Pasal 33 (1) Undang-Undang nomor 2 tahun 2017 dijelaskan Kantor perwakilan sebagaimana dimaksud dalam Pasal 32 huruf a wajib:

a. berbentuk badan usaha dengan kualifikasi yang setara dengan kualifikasi besar;

b. memiliki izin perwakilan badan usaha Jasa Konstruksi asing;

c. membentuk kerja sama operasi dengan badan usaha Jasa Konstruksi nasional berkualifikasi besar yang memiliki Izin Usaha dalam setiap kegiatan usaha Jasa Konstruksi di Indonesia;

d. mempekerjakan lebih banyak tenaga kerja Indonesia daripada tenaga kerja asing;

e. menempatkan warga negara Indonesia sebagai pimpinan tertinggi kantor perwakilan;

f. mengutamakan penggunaan material dan teknologi konstruksi dalam negeri;

g. memiliki teknologi tinggi, mutakhir, efisien, berwawasan lingkungan, serta memperhatikan kearifan lokal;

h. melaksanakan proses alih teknologi; dan i. melaksanakan kewajiban lain sesuai dengan ketentuan peraturan perundang-undangan.

(2) Izin perwakilan sebagaimana dimaksud pada ayat (1) huruf b diberikan oleh Menteri sesuai dengan ketentuan peraturan perundang-undangan.

(3) Kerja sama operasi sebagaimana dimaksud pada ayat (1) huruf c dilakukan dengan prinsip kesetaraan kualifikasi, kesamaan layanan, dan tanggung renteng.

Pasal 24 (1) Undang-Undang nomor 2 tahun 2017 dijelaskan dalam hal penyelenggaraan Jasa Konstruksi menggunakan anggaran pendapatan dan belanja daerah serta memenuhi kriteria berisiko kecil sampai dengan sedang, berteknologi sederhana sampai dengan madya, dan berbiaya kecil sampai dengan sedang, Pemerintah Daerah provinsi dapat membuat kebijakan khusus. (2) Kebijakan khusus sebagaimana dimaksud pada ayat (1) meliputi: a. kerja sama operasi dengan 
badan usaha Jasa Konstruksi daerah; dan/atau b. penggunaan Subpenyedia Jasa daerah.

Terbitnya Peraturan Menteri Pekerjaan Umum dan Perumahan nomor 14 Tahun 2020 tentang Standar dan Pedoman Pengadaan Jasa Konstruksi melalui Penyedia, cukup detail mengatur bagi penyedia yang berbentuk badan usaha dapat melaksanakan kerja sama operasi. Dijelaskan dalam Pasal 13 Permenpu nomor 14 Tahun 2020, kerja sama operasi dapat dilaksanakan sesama penyedia kualifikasi besar, sesama penyedia kualifikasi menengah, penyedia kualifikasi besar dengan penyedia kualifikasi menengah dan penyedia kualifikasi menengah dengan penyedia kualifikasi kecil. Menurut Permenpu nomor 14 Tahun 2020, kerja sama operasi tidak dapat dilaksanakan oleh penyedia kualifikasi besar dengan penyedia kualifikasi kecil dan sesama penyedia kualifikasi kecil.

Berikut contoh format perjanjian KSO dalam proses tender jasa konstruksi dalam Standar Dokumen Pemilihan (SDP);

\section{SURAT PERJANJIAN KERJA SAMA OPERASI (KSO)}

Sehubungan dengan tender pekerjaan..... maka kami:

........... [nama perusahaan peserta 1] .[nama perusahaan peserta 2] .[nama perusa haan peserta 3] [dan seterusnya]

bermaksud untuk mengikuti tender dan pelaksanaan kontrak secara bersama-sama dalam bentuk Kerja Sama Operasi (KSO).

Kami menyetujui dan memutuskan bahwa:

1. Secara bersama-sama:

a. Membentuk KSO dengan nama KSO adalah

b. Menunjuk ............. [nama perusahaan dari anggota KSO ini] sebagai perusahaan utama (leadfirm KSO ) untuk KSO dan mewakili serta bertindak untuk dan atas nama KSO.

c. Menyetujui apabila ditunjuk sebagai pemenang, wajib bertanggung jawab baik secara bersama-sama atau masing-masing atas semua kewajiban sesuai ketentuan dokumen kontrak.

2. Keikutsertaan modal (sharing) setiap perusahaan dalam KSO adalah: [nama perusahaan peserta 1 ]sebesar ..... \% (..... persen)

.......... [nama perusahaan peserta 2] sebesar ..... \% (.... persen) $\ldots \ldots \ldots \ldots$ [nama perusahaan peserta 3 ] sebesar ..... \% (.... persen)

............ [dst.]

3. Masing-masing peserta anggota $\mathrm{KSO}$, akan mengambil bagian sesuai sharing tersebut pada butir 2. dalam hal pengeluaran, keuntungan, dan kerugian dari KSO.

4. Pembagian sharing dalam KSO ini tidak akan diubah baik selama masa penawaran maupun sepanjang masa kontrak, kecuali dengan persetujuan tertulis terlebih dahulu dari Pejabat Pembuat Komitmen dan persetujuan bersama secara tertulis dari masingmasing anggota KSO. 
5. Terlepas dari sharing yang ditetapkan diatas, masing-masing anggota KSO akan melakukan pengawasan penuh terhadap semua aspek pelaksanaan dari perjanjian ini, termasuk hak untuk memeriksa keuangan, perintah pembelian, tanda terima, daftar peralatan dan tenaga kerja, perjanjian subkontrak, surat-menyurat, dan lain- lain.

6. Dalam pelaksanaan Tender sebagaimana disebutkan dalam perjanjian ini, kami menyatakan dan menyetujui pakta integritas:

a. Tidak akan melakukan praktik Korupsi, Kolusi, dan Nepotisme;

b. Akan mengikuti proses pengadaan secara bersih, transparan, dan profesional untuk memberikan hasil kerja terbaik sesuai ketentuan peraturan perundangundangan; dan

b. Apabila melanggar hal-hal yang dinyatakan dalam huruf $a$, dan b maka bersedia dikenakan sanksi administratif, dikenakan sanksi Daftar Hitam, digugat secara perdata dan/atau dilaporkan secara pidana sesuai dengan peraturan perundangundangan.

7. Wewenang menandatangani untuk dan atas nama KSO diberikan kepada [nama individu dari perusahaan leadfirm KSO] dalam kedudukannya sebagai direktur utama/direktur pelaksana ...[nama perusahaan dari leadfirm KSO] berdasarkan perjanjian ini.

8. Perjanjian ini berlaku sejak tanggal ditandatangani.

9. Perjanjian ini secara otomatis menjadi batal dan tidak berlaku lagi bila tender tidak dimenangkan oleh perusahaan KSO.

10.Perjanjian ini dibuat dalam rangkap mempunyai kekuatan hukum yang sama.

DENGAN KESEPAKATAN INI semua anggota kemitraan/KSO membubuhkan tanda tangan di pada hari tangg bulan , tahun

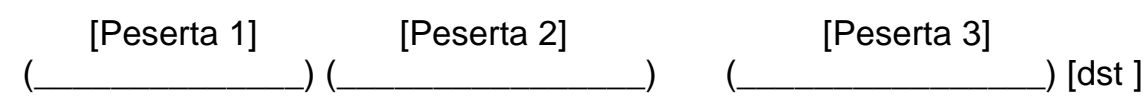

Catatan: Apabila ditetapkan sebagai pemenang tender maka Surat Perjanjian Kerja Sama Operasi ini harus dinotariatkan

\subsection{Praktek Berkontrak dengan Penyedia KSO dalam Pengadaan Barang/Jasa Pemerintah}

Dalam praktek di beberapa daerah, berkontrak dengan penyedia KSO cukup variasi. Menurut Danar PPK Universitas Tidar, ${ }^{12}$ dana yang bersumber dari APBN melalui dan proses pembayaran melalui KPPN yang bertanda tangan kontrak adalah yang ditunjuk dalam perjanjian KSO nya. Penyedia KSO harus membuat NPWP baru atas nama KSO tersebut. Karena membuat NPWP atas nama KSO maka pemungutan pajaknya sesuai NPWP KSO tersebut, tidak berkaitan dengan masingmasing perusahaan. Untuk membuat NPWP, setelah ditetapkan jadi pemenang, sebelum tanda tangan kontrak. Untuk mengurus NPWP KSO tidak sampai 5 hari sudah jadi. Yang agak lama itu kalau membuat PKP KSO nya bisa satu mingguan.

${ }^{12}$ Wawancara, Danar, PPK Universitas Tidar, 5 Desember 2019 melalui WhatsApp. 
Jadi dalam rentan waktu itu, harus dipenuhi. Kalau tidak terpenuhi maka kontrak tidak dapat lanjutkan.

Kalau surat perjanjian KSO ketika proses tender tidak harus melalui notaris cukup ada perjanjian KSO antara perusahaan yg ber KSO tersebut dengan dibubuhi materai. Praktiknya NPWP dan PKP juga sering kali dibuat setelah tanda tangan kontrak. Kalau tidak membuat PKP maka tidak dapat muncul Faktur Pajak atas nama KSO sehingga penarikan termin dan sebagainya tidak dapat dikeluarkan. NPWP juga dicantumkan untuk membuat Data Kontrak (ADK) untuk dilaporkan ke KPPN maksimal 5 hari kerja setelah kontrak di ttd. Jika diajukan lebih dari 5 hari kerja, KPPN akan meminta surat dispensasi dari KPA.

Rekening atas nama KSO tetap dibuat. KSO tidak memotong pajak dari masing-masing peserta KSO karena sudah selesai di NPWP dan PKP KSO itu saja. Untuk pembayaran tagihan dibayarkan atas nama KSO. Untuk membagi hasil atau sharing kepada masing-masing peserta KSO, PPK tidak bisa ikut campur, karena itu ranahnya perusahaan yang ber KSO. Jika ditemukan audit, pembagian kepada masing-masing peserta KSO tidak sesuai dalam perjanjian awal ketika ikut tender, auditor tidak berhak masuk ke ranah itu.

Misal proyek sudah selesai, status KSO yang dibentuk dapat dibubarkan. KSO bubar setelah pekerjaan selesai (FHO) karena didalam Perjanjian KSO tertulis untuk nama pekerjaan. NPWP dan PKP nya apakah tidak secara otomatis juga beku. Oleh karena itu KSO lapor ke KPP, bahwa KSO sudah selesai sehingga NPWP dan PKP dinonaktifkan. Kalo ada sengketa, nanti antara PPK dengan KSO, yang mewakili dari KSO semua anggota atau leadfearmnya. Jika salah satu anggota KSO keluar dari KSO yang dibentuk tidak boleh diganti dengan dengan penyedia lainnya.

Menurut Mandar Trisno Hadisaputra, ${ }^{13}$ kalau membuat KSO, maka harus entitas baru dengan akte pendirian dari notaris. Untuk proses pembayaran dengan sumber dana APBN dapat mengacu pada Peraturan Dirjen Perbendaharan Nomor 22/PB/2012 tentang Petunjuk Teknis Pelaksanaan Pembayaran Terhadap PihakPihak Tertentu Yang Melakukan Perjanjian Pengadaan Barang/Jasa Dengan

13 Wawancara, Mandar Trisno Hadisaputra, Praktisi Pengadaan Barang/Jasa Pemerintah, 21 Nopember 2019 melalui Whats App. 
Pemerintah secara Konsorsium. Sedangkan untuk proses pembayaran sumber dana APBD dapat diatur oleh masing-masing daerah atau menyesuaikan Peraturan Dirjen Perbendaharan Nomor 22/PB/2012. Dijelaskan dalam Pasal 3 Peraturan Dirjen Perbendaharan Nomor 22/PB/2012 bahwa tagihan atas pengadaan barang dan/atau jasa pemerintah yang dilaksanakan secara konsorsium yang dibayarkan kepada masing-masing perusahaan yang tergabung dalam konsorsium diajukan oleh salah satu perusahaan yang mewakili konsorsium kepada Kuasa Pengguna Anggaran. Tagihan tersebut diatur sebagai berikut :

a. Dibuat untuk masing-masing perusahaan yang tergabung dalam konsorsium sesuai dengan prestasi pekerjaan masing-masing perusahaan.

b. Dalam kontrak yang ditagihkan harus tercantum: nilai kontrak total dan bagian nilai kontrak untuk masing-masing perusahaan yang tergabung dalam konsorsium dan nomor rekening masing-masing perusahaan yang tergabung dalam konsorsium.

c. Berita Acara Pembayaran (BAP) dibuat dua yaitu; BAP Induk yang ditandatangani oleh salah satu perusahaan yang mewakili konsorsium dan BAP untuk masing-masing perusahaan yang tergabung dalam konsorsium.

d. Dalam tagihan pembayaran uang muka harus mencantumkan dengan jelas pada BAP nilai/porsi bagian uang muka untuk masing-masing perusahaan yang tergabung dalam konsorsium.

e. Dalam tagihan pembayaran prestasi pekerjaan/termin harus mencantumkan dengan jelas nilai porsi/bagian tagihan untuk masing-masing perusahaan pada Berita Acara Pemeriksaan Pekerjaan (BAPP) dan BAP.

Misal proyek sudah selesai, status KSO yang dibentuk dapat dibubarkan atau tidak, tergantung peserta KSO.

Menurut Heri Suroso, ${ }^{14}$ yang tanda tangan kontrak adalah Leader sesuai akte KSO, membuat NPWP baru atas nama KSO, sehingga pemotongan pajak atas nama KSO. Menurut Much Sakdudin, ${ }^{15}$ KSO dibentuk dengan menggabungkan 2

\footnotetext{
${ }^{14}$ Wawancara, Heri Suroso, Praktisi Pengadaan Barang/Jasa Pemerintah, 21 Nopember 2019 melalui Whats App.

15 Wawancara, Much Sakdudin, PPK Dinas Koperasi, UMKM, Perindustrian dan Perdagangan Kabuaten Pemalang , 21 Nopember 2019 melalui Whats App.
} 
badan usaha dengan disahkan oleh notaris dalam pekerjaan tertentu. NPWP menggunakan milik leader yang ditunjuk sesuai dengan perjajian KSO. Rekening atas nama KSO berdasarkan pengesahan notaris. Keuntungan atau kerugian dibagi sesuai dengan perjajian awal KSO. Ada yang cukup pakai rekening perusahaan induk untuk proses pembayaran tagihan.

Menurut Muhammad Nur Yahya, ${ }^{16}$ umumnya orang yang ditunjuk bersama pada Akta Notaris Pembentukan KSO sebagai penanggungjawab KSO yang menandatangani kontrak. Untuk sederhananya NPWP KSO dibuat bila telah ditetapkan sebagai pemenang, sedangkan waktu tender pakai NPWP masing-masing dahulu karena syarat kualifikasi masing-masing perserta dievaluasi, demikian juga perlakuannya dengan rekening KSO. Pemotongan pajak atas NPWP KSO, nanti masing-masing penanggungjawab KSO yang mengurus pemindahbukuan pemotongan pajak ke masing-masing NPWP perusahaan yang ber-KSO.

Dari uraian praktek berkontrak dengan penyedia KSO dalam PBJP menunjukan masih beragam, belum ada keseragaman. Berdasar penerapan berkontrak dengan penyedia KSO dapat dilihat bahwa:

a. Format surat perjanjian KSO dalam SDP tidak membatasi jenis KSO seperti apa yang harus dibentuk. Namun lebih condong mengarah bentuk KSO Administrasi, karena untuk penandatanganan kontrak diwakili oleh leadfirm.

b. Model pengajuan pembayaran sebagaimana Peraturan Dirjen Perbendaharan Nomor 22/PB/2012 condong ke arah KSO Administrasi, karena tagihan diajukan oleh salah satu perusahaan yang mewakili konsorsium. Namun demikian transfer pembayaran ke masing-masing rekening peserta KSO, sehingga pajak akan dipotong masing-masing peserta KSO. Dengan demikian KSO yang dibentuk tidak memotong pajak masing-masing peserta KSO sebagaimana ciri KSO Administrasi. Model tagihan yang dibuat untuk masing-masing perusahaan yang tergabung dalam konsorsium sesuai dengan prestasi pekerjaan masing-masing perusahaan berarti tanggungjawab kerja ada pada masing-masing anggota KSO yang mencerminkan bentuk KSO Non Administrasi. Wawancara, Muhammad Nur Yahya, Praktisi Pengadaan Barang/Jasa Pemerintah, 21 Nopember
2019 melalui Whats App. 
c. Beberapa praktek menggunakan bentuk KSO Administratif, namun KSO yang dibentuk tidak memotong masing-masing peserta KSO.

d. Kencenderungan menerapkan gabungan dari ciri-ciri bentuk KSO Administrasi dan KSO Non Administrasi.

e. Kebebasan bagi penyedia yang ber KSO untuk membentuk KSO seperti apa, apakah bentuk KSO Administrasi atau KSO Non Administrasi. Hal ini didasarkan adanya kebebasan bagi para peserta KSO akan membentuk KSO seperti apa.

f. Bentuk kerjasama bagi penyedia dalam PBJP familiar dikenal KSO, meskipun bentuk kerjasama dalam Pernyataan Standar Akuntansi Keuangan cukup beragam.

\section{Daftar Pustaka}

Ajik Sujoko, Permasalahan Subkontrak Pada Pekerjaan Konstruksi di Pemerintah, Adminitrative Law \& Governance Journal. Volume 2 Issue 3, August 2019.

Eka Suci Mauliyani, Ahmadi Miru, Nurfaidah Said, Kedudukan Perjanjian Kerja Sama Operasi (KSO) Dalam Hukum Perusahaan Di Indonesia, Analisis, Desember 2013, Vol.2 No.2 : $193-200$.

Ikatan Akuntansi Indonesia, 2013, Exposure Draft Pernyataan Standar Akuntansi Keuangan ED PSAK 66 Pengaturan Bersama, Jakarta, Dewan Standar Akuntansi Keuangan Ikatan Akuntan Indonesia.

Norsyakilah Romeli, Faridah Muhamad Halil, Faridah Ismail, Ani Saifuza Abd Shukor, Economic Challenges in Joint Venture Infrastructure Projects: Towards Contractor's Quality of Life, Procedia - Social and Behavioral Sciences 234 ( 2016 ) $19-27$.

Almaududi, Apa yang Dimaksud Dengan Kerjasama Operasi (KSO)?, https://almaududi.com/2019/01/05/apa-yang-dimaksud-dengan-kerjasamaoperasi-kso/, diunduh tanggal 16 Desember 2019, jam 11.26 WIB.

Bimo Satryo N, Jordan Sitorus, Nur Hidayah, Tugas Pelaporan Korporat PSAK 66 Operasi Bersama, https://www.academia.edu/13639718/PSAK_66, diunduh tanggal 17 Desember 2019, jam 12.27 WIB.

Dwi Martani, Pengaturan Bersama 66, https://staff.blog.ui.ac.id/martani/2018/03/15/pengaturan-bersama-psak-66/, diunduh tanggal 16 Desember 2019, jam 12.15

Istutik, Bentuk Joint Venture dalam PSAK 12 (Revisi 2009), http://blog.stiemce.ac.id/istutik/2012/02/29/bentuk-ventura-bersama-dalam-psak-12-revisi2009/, diunduh tanggal 18 Desember 2019, jam 10.38 WIB. 
Joint Operations and Joint Venture: IFRS 11/PSAK 66, Konsep, Struktur, Akuntansi dan Perpajakan di Indonesia, https://futurumcorfinan.com/wpcontent/uploads/2015/11/Joint_Venture_training_syllabus_Futurum_Corfinanfor-public.pdf, diunduh tanggal 16 Desember 219, jam 09.48 WIB.

Syarat, Tata Cara dan Dasar Hukum Kemitraan KSO, https://www.pengadaan.web.id/2017/11/syarat-tata-cara-dan-dasar-hukumkemitraan-kso.html, diunduh tanggal 16 Desember 2019, jam 13.53 WIB.

Undang-Undang nomor 2 tahun 2017 tentang Jasa Konstruksi

Peraturan Presiden nomor 16 tahun 2018 tentang Pengadaan Barang/Jasa Pemerintah

Peraturan LKPP Nomor 9 Tahun 2018 tentang Pedoman Pelaksanaan Pengadaan Barang/Jasa Melalui Penyedia

Peraturan Menteri Pekerjaan Umum dan Perumahan nomor 14 Tahun 2020 tentang Standar dan Pedoman Pengadaan Jasa Konstruksi melalui Penyedia

Wawancara, Danar, PPK Universitas Tidar, 5 Desember 2019 melalui WhatsApp.

Wawancara, Mandar Trisno Hadisaputra, Praktisi Pengadaan Barang/Jasa Pemerintah, 21 Nopember 2019 melalui Whats App.

Wawancara, Heri Suroso, Praktisi Pengadaan Barang/Jasa Pemerintah, 21 Nopember 2019 melalui Whats App.

Wawancara, Much Sakdudin, PPK Dinas Koperasi, UMKM, Perindustrian dan Perdagangan Kabuaten Pemalang, 21 Nopember 2019 melalui Whats App.

Wawancara, Muhammad Nur Yahya, Praktisi Pengadaan Barang/Jasa Pemerintah, 21 Nopember 2019 melalui Whats App. 